\title{
PENGARUH PEMAHAMAN LINGKUNGAN TERHADAP PERILAKU VANDALISME PENGUNJUNG TAMAN TERAS CIKAPUNDUNG DAN TAMAN LANSIA BANDUNG
}

\author{
Rizki Widya Witami ${ }^{(1)}$, Rosita ${ }^{(2)}$, Sri Marhanah ${ }^{(3)}$ \\ (1)(2)(3) Program Studi Manajemen Resort \& Leisure \\ Universitas Pendidikan Indonesia \\ rwidyawitami@yahoo.com
}

\begin{abstract}
ABSTRAK
Taman Teras Cikapundung dan Taman Lansia merupakan dua dari beberapa taman di Kota Bandung yang terdapat perilaku vandalisme, di lokasi tersebut dapat ditemukan sampah yang berserakan, fasilitas atau properti taman yang rusak, atau coretan-coretan tangan pengunjung. Penelitian ini bertujuan untuk mengetahui pengaruh pemahaman lingkungan terhadap perilaku vandalisme pengunjung Taman Teras Cikapundung dan Taman Lansia. Penelitian ini menggunakan metode deskriptif dengan pendekatan kuantitatif, melalui teknik random sample sebanyak 100 responden disetiap taman. Teknik analisa yang digunakan pada penelitian ini adalah teknik regresi linier berganda. Hasil penelitian ini menunjukan bahwa korelasi antar variabel didapatkan angka 0,381 untuk Taman Teras Cikapundung dan 0,333 untuk Taman Lansia, nilai tersebut termasuk dalam korelasi yang lemah. Dalam penelitian ini didapatkan pemahaman lingkungan di Taman Teras Cikapundung berpengaruh terhadap penurunan tingkat vandalisme sebesar $14,5 \%$ dan $11,10 \%$ untuk Taman Lansia, sisanya dipengaruhi oleh variabel lain yang tidak diteliti. Melihat hal tersebut, maka disarankan perlunya ditanamkan pemahaman mengenai lingkungan sejak dini pada masyarakat guna mengurangi tingkat vandalisme.
\end{abstract}

Kata Kunci : Pemahaman Lingkungan, Perilaku Vandalisme, dan Taman Kota

\section{THE EFFECT OF ENVIRONTMENTAL INSIGHT OF CONDUCT VANDALISM} BEHAVIOR IN TERAS CIKAPUNDUNG PARK AND LANSIA PARK BANDUNG

\begin{abstract}
Taman Teras Cikapundung and Taman Lansia are two of several parks in bandung there are vandalism behavior, in the location can be found garbage scattered, facilities or property garden damaged, or graffiti hands visitors.This research aims to determine the effect of Environmental Insight on behavior of vandalism Taman Teras Cikapundung and Taman Lansia. This research uses the descriptive method with the quantitative approach, through technique random sample as many as 100 respondents in every garden. Analysis techniques used in this reasearch are multiple linier regression techniques. The results of this research showed that the correlation between variables obtained for Taman Teras Cikapundung is $0.381 \%$ and $0.333 \%$ for Taman Lansia. the value are included in the weak correlation. In this research was obtained environmental insight in Taman Teras Cikapundung influential to reduce the level of vandalism reached $14.5 \%$ and $11,10 \%$ for Taman Lansia, the rest influenced by other variables that arent examined. Look at it, then suggested to instil an Environmental Insight early in the community in order to reduce the level of vandalism.
\end{abstract}


Keywords: Environmental Insight, Vandalism Behavior and City Park

\section{PENDAHULUAN}

Kota Bandung menurut Dinas Pertamanan dan Pemakaman Kota Bandung memiliki Ruang Terbuka Hijau seluas 1700 hektare. Kota Bandung yang memiliki suasana yang sejuk dengan tumbuhan dan pepohonan yang masih terbilang banyak, membuat masyarakat dan pemerintah berupaya untuk mengelola ruang terbuka hijau yang terdapat di Kota Bandung sebagai taman. Hal tersebut bertujuan agar ruang terbuka hijau yang berada di Kota Bandung dapat bermanfaat bagi masyarakat khususnya warga Kota Bandung sendiri. Untuk itu pemerintah kota berupaya untuk mengelola taman-taman yang ada di Kota Bandung. Tidak hanya sebatas taman biasa yang sering kita jumpai seperti dulu, kini pemerintah memberikan inovasi-inovasi baru terhadap taman-taman yang berada di Kota Bandung. Dari jumlah taman yang dimiliki oleh Kota Bandung, sebagian akan dijadikan taman tematik oleh pemerintah. Taman-taman tersebut nantinya memiliki fasilitas, fungsi dan konsep yang berbeda-beda. Hal tersebut bertujuan agar masyarakat Kota Bandung memiliki ruang publik dengan fungsi dan pengalaman yang berbeda untuk sekedar berekreasi dan mengabiskan waktu dengan keluarga maupun rekan. Seperti yang kita ketahui, sudah banyak taman-taman yang diubah dan diperbaharui oleh pemerintah untuk ruang publik masyarakat dengan konsep dan fasilitas yang berbeda-beda. Taman-taman di Kota Bandung tersebut sudah mulai dapat digunakan oleh masyarakat baik itu yang berasal dari Kota Bandung maupun luar Kota Bandung seperti Taman Pasupati, Taman Jomblo, Taman Musik, Taman Vanda, Taman Film, Taman Alun-Alun Kota Bandung dan masih banyak lagi. Berikut adalah daftar taman tematik yang telah selesai direalisasikan oleh pemerintah kota Bandung adalah:

Tabel 1. Daftar Taman Tematik di Kota Bandung

\begin{tabular}{ccc}
\hline No & Nama Taman & $\begin{array}{c}\text { Tanggal } \\
\text { Peresmian }\end{array}$ \\
\hline 1 & Taman Fotografi & 21 Desember 2013 \\
\hline
\end{tabular}

\begin{tabular}{cll}
\hline No & \multicolumn{1}{c}{ Nama Taman } & \multicolumn{1}{c}{$\begin{array}{c}\text { Tanggal } \\
\text { Peresmian }\end{array}$} \\
\hline 2 & Taman Pustaka Bunga & 30 Desember 2013 \\
\hline 3 & $\begin{array}{l}\text { Taman Alun-Alun } \\
\text { Bandung }\end{array}$ & 31 Desember 2014 \\
\hline 4 & Taman Lansia & 31 Desember 2014 \\
\hline 5 & $\begin{array}{l}\text { Taman Jomblo / Taman } \\
\text { Pasupati }\end{array}$ & 1 Januari 2014 \\
\hline 6 & Taman Skatepark & 1 Januari 2014 \\
\hline 7 & Taman Musik Centrum & 1 Maret 2014 \\
\hline 8 & Taman Film & 14 September \\
\hline 9 & $\begin{array}{l}\text { Taman Teras } \\
\text { Cikapundung }\end{array}$ & 30 Januari 2016 \\
\hline
\end{tabular}

Sumber: Olahan penulis (2016)

Taman Teras Cikapundung atau yang dikenal sebagai $\mathrm{TeCi}$ atau Amphitheatre Cikapundung diresmikan pada tanggal 30 Januari 2016. Berpadu dengan alam hijau dan sungai yang selama ini dikenal menjadi ciri Babakan Siliwangi. Taman Teras Cikapundung sendiri memiliki beberapa zona wisata, antara lain Jembatan Merah yaitu jembatan berlantai kayu selebar tiga meter yang bercat merah pada gerbang dan tiangnya menjadi penghubung di antara bantaran Sungai Cikapundung. Melihat potensi yang dimiliki oleh Taman Teras Cikapundung sendiri membuat beberapa masyarakat tergerak untuk membantu pemerintah dalam mengelola Taman Teras Cikapundung sebagai fasilitas kota dengan membuat suatu komunitas dengan nama Komunitas Taman Teras Cikapundung.

Selain itu, adapun taman yang dikelola dan direnovasi ulang oleh pemerintah sehingga menarik banyak perhatian dari pengunjung untuk sekedar menghabiskan waktu luang mereka bersama keluarga maupun bersama kerabat. Taman tersebut ialah Taman Lansia yang berada di sebelah kanan Gedung Sate tidak jauh dari Pusdai Bandung dan pusat jajanan yang tepatnya berada di Jalan Cisangkuy. Taman Lansia atau yang kita ketahui singkatan dari Taman Lanjut Usia sebenarnya sudah berdiri sejak tahun 1995 dan pada saat itu taman tersebut memang digunakan sebagai tempat berkumpulnya 
para lansia sehingga taman tersebutpun dinamakan demikian. Di taman ini kita dapat melihat danau buatan yang telah diresmikan oleh sang walikota. Danau retensi ini memiliki luas lebih dari 1500 meter persegi untuk danau pertama, dan 600 meter persegi untuk danau kedua. Selain danau buatan yang berfungsi sebagai penampung air saat hujan tiba dan sarana untuk mereduksi banjir.

Melihat banyaknya antusiasme masyarakat terhadap taman-taman yang kini kian bermunculan di Kota Bandung dengan konsep taman dan fungsi yang berbeda-beda, banyak masyarakat yang memilih menghabiskan waktu luangnya dengan pergi mengunjung taman-taman yang ada di Kota Bandung. Namun, tak jarang pula banyak pengunjung taman yang melupakan fungsi sebenarnya dari taman kota itu sendiri. Banyaknya pengunjung yang tidak menghiraukan kelestarian lingkungan taman kota tersebut. Pengunjung taman kota pada umumnya melakukan kegiatan seperti mengababadikan momen, menikmati fasilitas yang disediakan, bahkan hanya sekedar bersantai dan menikmati suasana alam yang disuguhkan oleh taman kota tersebut. Tetapi secara tidak sadar, pengunjung yang datang ke taman kota justru menurunkan dan merusak kualitas taman kota itu sendiri dengan merusak tanaman, mecorat-coret fasilitas umum yang disediakan, membuang sampah sembarangan dan melanggar aturan yang telah ditetapkan oleh pihak pemerintah dan pengelola. Hal tersebut dapat dengan mudah kita temui bila berkunjung ke taman-taman kota yang ada di Bandung dan tidak sedikit pula masyarakat yang mengeluh karena pemandangan vandalisme yang mengganggu tersebut.

Berdasarkan hasil observasi langsung peneliti ke lapangan yaitu Taman Teras Cikapundung dan Taman Lansia, penulis mendapatkan hasil bahwa kualitas lingkungan dari kedua taman kota yang peneliti jadikan sebagai studi kasus tersebut perlu diperhitungkan kembali. Karena peneliti menemukan beberapa fasilitas dan kebersihan lingkungan yang berada di kedua taman kota tersebut masih harus diperhatikan. Karena walaupun sudah diberi tanda larangan untuk tidak membuang sampah sembarangan dan tidak merusak lingkungan terutama tanaman, masih banyak pengunjung yang mengabaikan tanda larangan tersebut. Masih banyaknya pengunjung yang kurang memperhatikan kelestarian lingkungan dengan membuang sampah sembarangan, tidak menjaga fasilitas umum dengan baik, dan tentunya tidak menjaga kelestarian makhluk hidup lain yang berada di taman kota tersebut. Kegiatan yang dapat disebut sebagai perilaku vandalisme itu tentunya berdampak kurang baik pada taman kota tersebut dan hal tersebut dapat dilihat langsung secara kasat mata oleh siapapun yang tentunya membuat fungsi dari taman kota sebagai fasilitas umum untuk menghabiskan waktu luang berkurang.

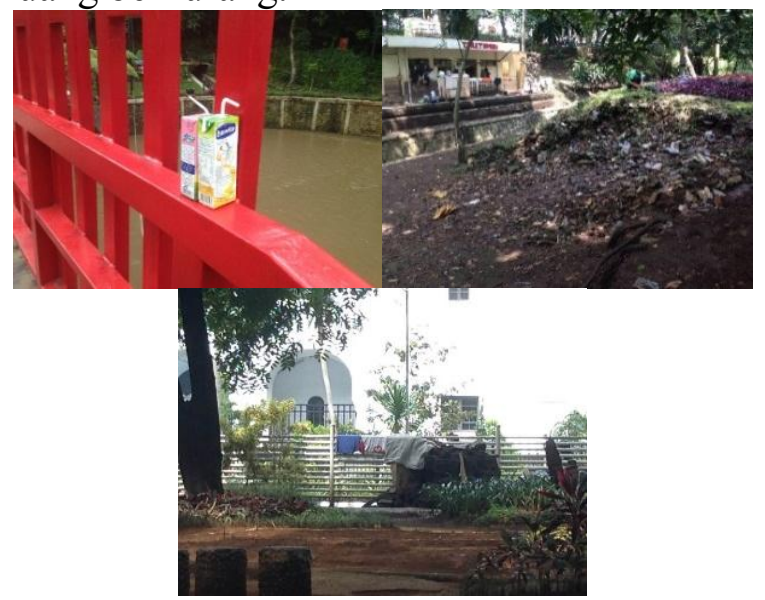

\section{Gambar 1. Vandalisme yang Ditemukan di Taman Teras Cikapundung dan Taman Lansia}

Sumber: Dokumentasi Pribadi, 2016

Pada gambar 1 menunjukkan beberapa perilaku vandalisme yang peneliti temukan di Taman Teras Cikapundung dan Taman Lansia Bandung. Hal tersebut dapat dilihat pada gambar pertama dan kedua berlokasi di Taman Lansia Bandung yang mana dapat ditemukannya sampah yang menumpuk di taman tersebut dan pada gambar kedua ialah pagar pembatas taman yang rusak karena pengunjung atau pedagang yang berada di 
taman tersebut tidak memperhatikan dampak yang akan terjadi dari perbuatan terhadap fasilitas atau properti taman. Pada gambar ketiga berlokasi di Taman Teras Cikapundung menunjukkan sampah yang tidak dibuang pada tempatnya sehingga mengganggu pemandangan taman.

Gambar dan beberapa ulasan mengenai perilaku vandalisme yang terjadi di Taman Kota Bandung tersebut menjelaskan mengenai seberapa jauh kerusakan yang telah ditimbulkan akibat perilaku vandalisme yang dilakukan oleh pengunjung Taman Kota Bandung. Salah satu penyebab terjadinya perilaku vandalisme tersebut adalah bagaimana dan sejauh mana pemahaman pengunjung taman kota terhadap lingkungan itu sendiri sehingga dapat terjadinya perilaku vandalisme khususnya di Taman Kota Bandung.

Tujuan dari penelitian ini adalah untuk mengetahui seberapa besar pengaruh pemahaman lingkungan terhadap perilaku vandalisme yang dilakukan oleh pengunjung Taman Teras Cikapundung dan Taman Lansia Bandung. Hasil dari penelitian ini dapat dipakai sebagai bahan masukan untuk pihak pengelola taman di kota Bandung dalam mempertahankan fungsi fasilitas yang ada dan juga sebagai bahan referensi bagi pengunjung dalam mengambil keputusan untuk berkunjung ke Taman Kota Bandung.

\section{LANDASAN TEORI}

Menurut Hamzah (2013:20) terdapat beberapa pemahaman manusia terhadap lingkungannya yang pertama yaitu Antroposentris yang menyebutkan bahwa alam diciptakan sebagai penyedia sumber daya untuk dieksploitasi semaksimal mungkin, ditaklukan dan dikuasai oleh manusia. Pemahaman Ekosentris menyebutkan bahwa manusia adalah bagian dari ekosistem alam sehingga manusia harus menghargai nilai instrinsik unsur-unsur alam dan memperhatikan pemberdayaan alam. Dan yang terakhir yaitu pemahaman Biosentris yang menyebutkan bahwa alam berhak untuk dihargai karena alam dan manusia memiliki nilai moral yang sama. Perilaku vandalisme ialah segala macam perilaku yang menyebabkan kerusakan atau penghancuran benda pribadi atau publik (Haryadi dan Setiawan, 1995). Perilaku vandalisme terjadi atas beberapa motif atau tujuan yang berbeda-beda seperti yang dikatakan oleh Cohen (1973) membagi beberapa jenis perilaku vandalisme yang terjadi berdasarkan motif atau latar belakang pelaku yaitu Acquistive Vandalism yang bertujuan untuk mendapatkan barang atau uang, Tactical Vandalisme yang dilakukan dengan motivasi mencapai suatu tujuan selain uang, Ideological Vandalisme adalah perilaku merusak yang didasari oleh perusahaan untuk mempromosikan kelompok sosial atau politik atau yang lainnya, Vindictive Vandalism adalah perilaku merusak yang bertujuan untuk membalas dendam, Play Vandalism dilakukan untuk keisengan belaka dan Malicious Vandalism perilaku merusak untuk mengekspresikan kemarahan atau frustasi pelaku.

\section{METODE}

Metode penelitian yang digunakan dalam penelitian ini adalah penelitian deskriptif dengan menggunakan pendekatan kuantitatif. Menurut Nazir (1988: 63), metode deskriptif merupakan suatu metode dalam meneliti status sekelompok manusia, suatu objek, suatu set kondisi, suatu sistem pemikiran ataupun suatu kelas peristiwa pada masa sekarang. Populasi dalam penelitian ini adalah jumlah penduduk Kota Bandung pada tahun 2012 hingga 2014 dan sampel yang diambil ialah sebanyak 200 responden disetiap taman dan menggunakan teknik Random Sampling atau sampel acak. Menurut Arikunto (2010, hlm. 177) teknik sampling ini diberi nama demikian karena di dalam pengambilan sampelnya, peneliti "mencampur" subjek-subjek di dalam populasi sehingga semua subjek dianggap sama.

Variabel dalam penilitian ini adalah pemahaman lingkungan dan perilaku 
vandalisme. Analisis data yang digunakan dalam penelitian ini adalah analisis regresi berganda. Untuk analisis data penelitian ini menggunakan tabulasi data, garis kontinum, regresi linier berganda, koefisien determinasi, dan uji hipotesis.

\section{HASIL DAN PEMBAHASAN}

Taman Teras Cikapundung diresmikan pada tanggal 30 Januari 2016 oleh Direktur Jenderal Sumber Daya Air (SDA) Kemen PUPR Mudjiadi, Wali Kota Bandung Ridwan Kamil, Asda II Pemprov Jabar Deni Juanda dan mantan Menteri PU Djoko Kirmanto. Dalam sejarah pembuatan taman di era Ridwan Kamil, ini pertama kalinya dia menggusur warga. Proses penggusurannya dilakukan secara baik-baik dengan melakukan dialog dengan warga, menuruti aspirasi warganya, dan lainnya. Sebagian warga yang mendiami bantaran sungai Cikapundung di Jalan Siliwangi dipindahkan ke rumah susun di daerah Sadang Serang.

Taman Teras Cikapundung menjadi tempat berkumpulnya masyarakat, komunitas, dan seniman-seniman di Bandung. Berpadu dengan alam hijau dan sungai yang selama ini dikenal menjadi ciri Babakan Siliwangi. Melihat potensi yang dimiliki oleh Taman Teras Cikapundung sendiri membuat beberapa masyarakat tergerak untuk membantu pemerintah dalam mengelola Taman Teras Cikapundung sebagai fasilitas kota dengan membuat suatu komunitas dengan nama Komunitas Taman Teras Cikapundung. Selain menikmati pemandangan sungai, pengunjung yang datang ke taman ini pun dapat melakukan aktivitas rafting di sungai dengan biaya yang relatif murah untuk Dewasa dikenakan biaya sebesar Rp 10.000 dan untuk anak - anak dikenakan biaya sebesar Rp 5.000,-. Selain itu pengelola pun menyediakan paket rafting lain yang lebih menantang dan berada diluar area Taman Teras Cikapundung diantaranya paket rafting dan Kukuyaan dengan kisaran biaya sebesar Rp 50.000 - Rp 100.000 tergantung dari jarak yang ditempuh. Setiap hari Sabtu dan Minggu pengelola Taman
Teras Cikapundung akan menyalakan air mancur yang berada ditengah Taman Teras Cikapundung untuk menghibur pengunjung yang ada. Uniknya ialah air mancur tersebut akan mengeluarkan suara-suara yang diiringi dengan lampu yang indah.

Taman Lansia Bandung adalah sebuah taman kota yang menjadi area hijau, salah satu paru-paru kota Bandung. Taman ini terletak di Jalan Cisangkuy yang lokasinya bersebrangan dengan Gedung Sate, pusat pemerintahan Provinsi Jawa Barat. Taman Lansia ini ialah taman kota yang dikelola dan direnovasi ulang oleh pemerintah sehingga menarik kembali banyak perhatian dari masyarakat. Taman Lansia atau yang kita ketauhi singkatan dari Taman Lanjut Usia sebenarnya sudah berdiri sejak tahun 1995.

Untuk masuk ke Taman Lansia ini sendiri tidak dipungut biaya apapun. Di taman ini kita dapat melihat danau buatan yang telah diresmikan oleh sang walikota sendiri. Danau retensi ini memiliki luas lebih dari 1500 meter persegi untuk danau pertama dan 600 meter persegi untuk danau kedua. Selain danau buatan yang berfungsi sebagai penampung air saat hujan tiba dan sarana untuk mereduksi banjir. Taman ini menyediakan Wifi atau internet gratis untuk pengunjung guna menarik perhatian pengunjung untuk datang ke taman ini. Aktivitas yang dapat dilakukan ditaman ini selain bersantai dan menikmati suasana alam yang ada yaitu terdapat Jogging Track, Hammock dan jasa penyewaan kuda.

Untuk mengetahui tanggapan responden mengenai pemahaman lingkungan akan diketahui dengan tabel sebagai berikut:

Tabel 2. Rekapitulasi Tanggapan

Pengunjung Taman Teras Cikapundung Terhadap Pemahaman Lingkungan

\begin{tabular}{ccccc}
\hline No & $\begin{array}{c}\text { Sub. } \\
\text { Variabel }\end{array}$ & Skor & Presentase & Kategori \\
\hline 1. & Antroposentris & 1159 & $58 \%$ & $\begin{array}{c}\text { Cukup } \\
\text { Paham }\end{array}$ \\
\hline 2. & Ekosentris & 1713 & $85,6 \%$ & $\begin{array}{l}\text { Sangat } \\
\text { Paham }\end{array}$ \\
\hline 3. & Biosentris & 1633 & $81,6 \%$ & Paham \\
\hline
\end{tabular}




\begin{tabular}{cccc}
\hline Jumlah Skor & $\mathbf{4 5 0 5}$ & $\mathbf{7 5} \%$ & Paham \\
\hline Sumber: Olahan Penulis, 2016 &
\end{tabular}

Tabel 2 menggambarkan Rekapitulasi Tanggapan Pengunjung Taman Teras Cikapundung terhadap Pemahaman Lingkungan. Secara keseluruhan tanggapan responden yang ada di Taman Teras Cikapundung mengenai pemahaman lingkungan mendapatkan skor sebesar 4505 . Jumlah skor tersebut dimasukkan ke dalam garis kontinum yang pengukurannnya sebagai berikut:

Nilai Indeks Maksimum $=5 \times 12 \times 100=$ 6000

Nilai Indeks Minimum $=1 \times 12 \times 100=$ 1200

Jarak Interval $=($ nilai maks - nilai $\min ): 5$

$$
=(6000-1200): 5
$$$$
=960
$$

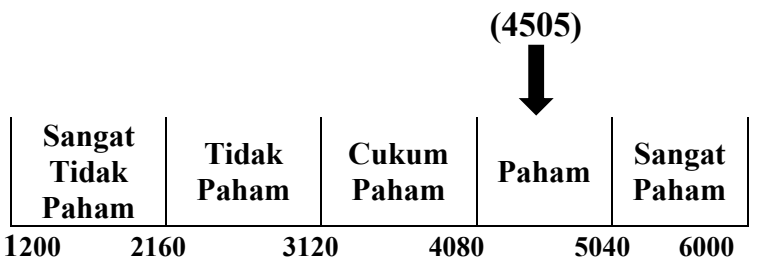

Gambar 2. Garis Kontinum Pemahaman Lingkungan Pengunjung Taman Teras Cikapundung

Sumber: Olahan Penulis, 2016

Gambar 2 menunjukan bahwa pengunjung Taman Teras Cikapundung berada pada kategori "paham" terhadap pemahaman mengenai lingkungan. Skor yang diharapkan untuk jawaban responden terhadap pernyataan mengenai pemahaman lingkungan adalah 6000. Dari perhitungan tabel diatas menunjukkan nilai yang diperoleh yaitu sebesar 4505 atau $75 \%$ dengan pemahaman lingkungan terbanyak pengunjung Taman Teras Cikapundung ialah pemahaman Ekosentris.

Tabel 3. Rekapitulasi Tanggapan

Pengunjung Taman Lansia Terhadap Pemahaman Lingkungan

\begin{tabular}{clccc}
\hline No. & Sub. Variabel & Skor & Presentase & Kategori \\
\hline 1. & Antroposentris & 1260 & $63 \%$ & $\begin{array}{l}\text { Cukup } \\
\text { Paham }\end{array}$ \\
\hline 2. & Ekosentris & 1782 & $89,1 \%$ & $\begin{array}{l}\text { Sangat } \\
\text { Paham }\end{array}$ \\
\hline
\end{tabular}

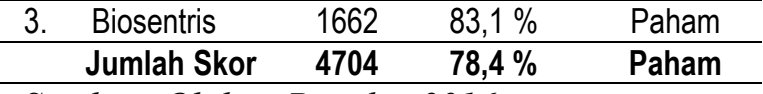

Sumber: Olahan Penulis, 2016

Tabel 3 menggambarkan Rekapitulasi Tanggapan Pengunjung Taman Lansia terhadap Pemahaman Lingkungan. Secara keseluruhan tanggapan responden yang ada di Taman Lansia mengenai pemahaman lingkungan mendapatkan skor sebesar 4707. Jumlah skor tersebut dimasukkan ke dalam garis kontinum yang pengukurannnya sebagai berikut:

Nilai Indeks Maksimum $=5 \times 12 \times 100=$ 6000

Nilai Indeks Minimum $=1 \times 12 \times 100=$ 1200

Jarak Interval $=($ nilai maks - nilai $\min ): 5$

$$
\begin{aligned}
& =(6000-1200): 5 \\
& =960
\end{aligned}
$$

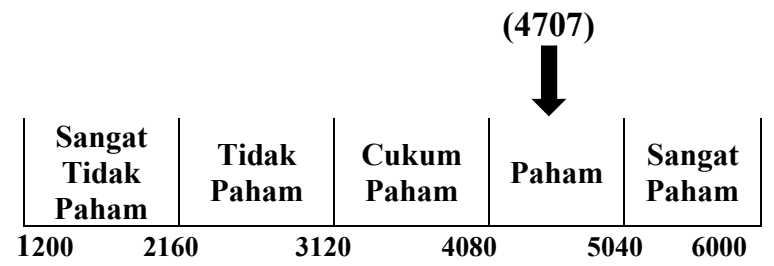

Gambar 3. Garis Kontinum Pemahaman

Lingkungan Pengunjung Taman Lansia Sumber: Olahan Penulis, 2016

Gambar 3 menunjukan bahwa pengunjung Taman Lansia berada pada posisi "paham" terhadap pemahaman mengenai lingkungan. Skor yang diharapkan untuk jawaban responden terhadap pernyataan mengenai pemahaman lingkungan adalah 6000. Dari perhitungan dalam Tabel 4.8. menunjukkan nilai yang diperoleh yaitu sebesar 4704 atau 78,4\% dengan pemahaman lingkungan terbanyak pengunjung Taman Lansia ialah paham Ekosentris.

Untuk perilaku vandalisme yang terjadi di Taman Teras Cikapundung dan Taman Lansia Bandung akan diketahui dengan melihat tabel berikut ini:

Tabel 4. Rekapitulasi Tanggapan Pengunjung Taman Teras Cikapundung Terhadap Perilaku Vandalisme

Sub.
No. Skoriabel Presentase Kategori


Rizki Widya Witami, Rosita dan Sri Marhanah: Pengaruh Pemahaman Lingkungan Terhadap

Perilaku Vandalisme Pengunjung Taman Teras Cikapundung dan Taman Lansia Bandung

\begin{tabular}{ccccc}
\hline 1. & $\begin{array}{l}\text { Acquistive } \\
\text { Vandalisme }\end{array}$ & 140 & $28 \%$ & $\begin{array}{c}\text { Tidak } \\
\text { Pernah }\end{array}$ \\
\hline 2. & $\begin{array}{l}\text { Tactical } \\
\text { Vandalisme }\end{array}$ & 242 & $24,2 \%$ & $\begin{array}{c}\text { Tidak } \\
\text { Pernah }\end{array}$ \\
\hline 3. & $\begin{array}{l}\text { Ideological } \\
\text { Vandalisme }\end{array}$ & 286 & $28,6 \%$ & $\begin{array}{c}\text { Tidak } \\
\text { Pernah }\end{array}$ \\
\hline 4. & $\begin{array}{l}\text { Vindictive } \\
\text { Vandalisme }\end{array}$ & 236 & $23,6 \%$ & $\begin{array}{c}\text { Tidak } \\
\text { Pernah }\end{array}$ \\
\hline 5. & $\begin{array}{l}\text { Play } \\
\text { Vandalisme }\end{array}$ & 490 & $49 \%$ & $\begin{array}{c}\text { Tidak } \\
\text { Pernah }\end{array}$ \\
\hline 6. & $\begin{array}{l}\text { Malicious } \\
\text { Vandalisme }\end{array}$ & 124 & $12,4 \%$ & $\begin{array}{c}\text { Tidak } \\
\text { Pernah }\end{array}$ \\
\hline Jumlah Skor & 1518 & $\mathbf{2 5 , 3} \%$ & $\begin{array}{c}\text { Tidak } \\
\text { Pernah }\end{array}$ \\
\hline
\end{tabular}

Sumber: Olahan Penulis, 2016

Dari data yang diolah pada tabel 4 diperoleh nilai total sebesar 1518 atau sebesar 25,3 \% dari total responden pengunjung Taman Teras Cikapundung menyatakan tidak pernah melakukan semua jenis perilaku vandalisme yang kerap terjadi di taman kota atau sebesar $74,7 \%$ pengunjung menyatakan pernah melakukan perilaku vandalisme di Taman Teras Cikapundung. Tanggapan pengunjung Taman Teras Cikapundung dapat lebih jelas terlihat melalui garis kontinum berikut ini:

Nilai Indeks Maksimum $=5 \times 12 \times 100=$ 6000

Nilai Indeks Minimum $=1 \times 12 \times 100=$ 1200

Jarak Interval $=($ nilai maks - nilai $\min ): 5$

$$
\begin{aligned}
& =(6000-1200): 5 \\
& =960
\end{aligned}
$$

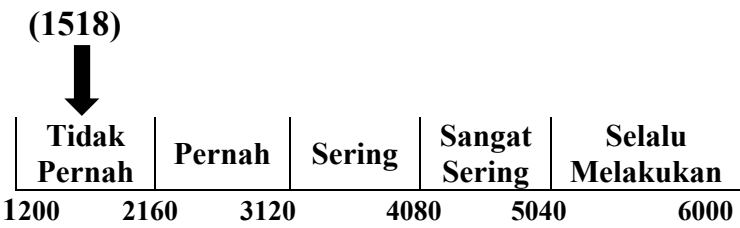

Gambar 4. Garis Kontinum Perilaku Vandalisme Pengunjung Taman Teras Cikapundung

Sumber: Olahan Penulis, 2016

Gambar 4 menunjukan bahwa pengunjung Taman Teras Cikapundung berada pada posisi "tidak pernah". Dengan nilai tersebut dari skor ideal 6000 yang artinya sebesar $25,3 \%$ dari total responden pengunjung Taman Teras Cikapundung menyatakan tidak pernah melakukan semua jenis perilaku vandalisme yang kerap terjadi di taman kota atau sebesar 74,7\% pengunjung menyatakan pernah melakukan perilaku vandalisme di Taman Teras Cikapundung.

Tabel 5. Rekapitulasi Tanggapan Pengunjung Taman Lansia Terhadap Perilaku Vandalisme

\begin{tabular}{clccc}
\hline No. & $\begin{array}{c}\text { Sub. } \\
\text { Variabel }\end{array}$ & Skor & Presentase & Kategori \\
\hline 1. & $\begin{array}{l}\text { Acquistive } \\
\text { Vandalisme }\end{array}$ & 158 & $31,6 \%$ & $\begin{array}{c}\text { Tidak } \\
\text { Pernah }\end{array}$ \\
\hline 2. & $\begin{array}{l}\text { Tactical } \\
\text { Vandalisme }\end{array}$ & 268 & $26,8 \%$ & $\begin{array}{c}\text { Tidak } \\
\text { Pernah }\end{array}$ \\
\hline 3. & $\begin{array}{l}\text { Ideological } \\
\text { Vandalisme }\end{array}$ & 302 & $30,2 \%$ & $\begin{array}{c}\text { Tidak } \\
\text { Pernah }\end{array}$ \\
\hline 4. & $\begin{array}{l}\text { Vindictive } \\
\text { Vandalisme }\end{array}$ & 268 & $26,8 \%$ & $\begin{array}{c}\text { Tidak } \\
\text { Pernah }\end{array}$ \\
\hline 5. & $\begin{array}{l}\text { Play } \\
\text { Vandalisme }\end{array}$ & 514 & $51,4 \%$ & $\begin{array}{c}\text { Tidak } \\
\text { Pernah }\end{array}$ \\
\hline 6. & $\begin{array}{l}\text { Malicious } \\
\text { Vandalisme }\end{array}$ & 136 & $13,6 \%$ & $\begin{array}{c}\text { Tidak } \\
\text { Pernah }\end{array}$ \\
\hline & Jumlah Skor & 1646 & $\mathbf{2 7 , 4} \%$ & $\begin{array}{c}\text { Tidak } \\
\text { Pernah }\end{array}$ \\
\hline
\end{tabular}

Sumber: Olahan Penulis, 2016

Dari data yang diolah pada tabel 5 diperoleh nilai total sebesar 1646 atau sebesar 27,4 \% dari total responden pengunjung Taman Lansia menyatakan tidak pernah melakukan semua jenis perilaku vandalisme yang kerap terjadi di taman kota atau sebesar $72,6 \%$ pengunjung menyatakan pernah melakukan perilaku vandalisme di Taman Lansia. Tanggapan pengunjung Taman Lansia dapat lebih jelas terlihat melalui garis kontinum berikut ini:

Nilai Indeks Maksimum $=5 \times 12 \times 100=$ 6000

Nilai Indeks Minimum $=1 \times 12 \times 100=$ 1200

Jarak Interval $=($ nilai maks- nilai $\min ): 5$

$$
\begin{aligned}
& =(6000-1200): 5 \\
& =960
\end{aligned}
$$

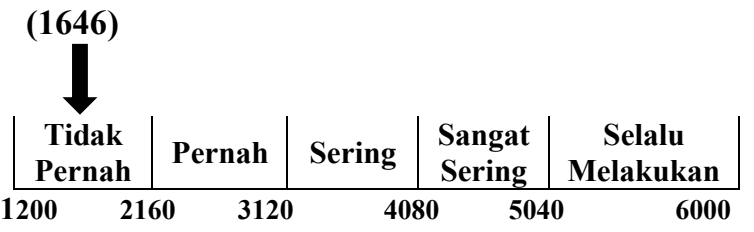

Gambar 5. Garis Kontinum Perilaku Vandalisme Pengunjung Taman Lansia Sumber: Olahan Penulis, 2016 
Gambar 5 menunjukan bahwa pengunjung Taman Lansia berada pada posisi "tidak pernah". Dengan nilai tersebut dari skor ideal 6000 yang artinya sebesar $27,4 \%$ dari total responden pengunjung Taman Lansia menyatakan tidak pernah melakukan semua jenis perilaku vandalisme yang kerap terjadi di taman kota atau sebesar $72,6 \%$ pengunjung menyatakan pernah melakukan perilaku vandalisme di Taman Lansia.

Setelah kondisi dari masing-masing variabel diketahui, langkah selanjutnya adalah mencari tahu apakah variabelvariabel tersebut saling mempengaruhi satu sama lain. Pengaruh yang akan diuji ialah pemahaman lingkungan terhadap perilaku vandalisme di Taman Teras Cikapundung dan Taman Lansia Bandung. Untuk mengetahui pengaruh tersebut maka digunakanlah analisis regresi linier berganda sebagai berikut:

Dimana :

$$
\mathbf{Y}=\mathbf{a}+\mathbf{b}_{1} \mathbf{X}_{1}+\mathbf{b}_{2} \mathbf{X}_{2}+\mathbf{b}_{3} \mathbf{X}_{3}
$$

$$
\begin{array}{ll}
\mathrm{Y} & =\text { Perilaku Vandalisme } \\
\mathrm{X}_{1} & =\text { Pemahaman Antroposentris } \\
\mathrm{X}_{2} & =\text { Pemahaman Ekosentris } \\
\mathrm{X}_{3} & =\text { Pemahaman Biosentris } \\
\mathrm{a} & =\text { Konstanta } \\
\mathrm{b} & =\text { Koefisien Regresi }
\end{array}
$$

\begin{tabular}{|c|c|c|c|c|c|c|}
\hline \multirow{2}{*}{\multicolumn{2}{|c|}{ Model }} & \multicolumn{2}{|c|}{$\begin{array}{l}\text { Unstandardized } \\
\text { Coefficients }\end{array}$} & \multirow[t]{2}{*}{$\begin{array}{r}\text { Standardized } \\
\text { Coefficients } \\
\end{array}$} & \multirow[t]{2}{*}{$t$} & \multirow[t]{2}{*}{ Sig } \\
\hline & & B & $\begin{array}{l}\text { Std. } \\
\text { Error }\end{array}$ & & & \\
\hline \multirow[t]{4}{*}{1} & (Constant) & 29.698 & 4.379 & & 6.781 & .000 \\
\hline & $\begin{array}{l}\text { Antroposentris } \\
\text { (X1) }\end{array}$ & .005 & .266 & .002 & .019 & .985 \\
\hline & Ekosentris (X2) & -.736 & .295 & -.281 & -2.495 & .014 \\
\hline & Biosentris (X3) & -.357 & .276 & -.146 & -1.295 & .198 \\
\hline
\end{tabular}

Dengan menggunakan bantuan software SPSS diperoleh hasil sebagai berikut:

Tabel 6. Regresi Linier Berganda Taman Teras Cikapundung

Sumber: Hasil Olahan Menggunakan SPSS

Versi 20.0, 2016

Persamaan regresi yang menjelaskan pengaruh pemahaman lingkungan Antroposentris $\left(\mathrm{X}_{1}\right)$, Ekosentris $\left(\mathrm{X}_{2}\right)$ dan Biosentris $\left(\mathrm{X}_{3}\right)$ terhadap perilaku vandalisme (Y) pengunjung Taman Teras Cikapundung adalah sebagai berikut:

$$
Y=29,698+0,005 X_{1}+(-0,736) X_{2}+(-0,357) X_{3}
$$

Nilai konstanta $(\alpha)$ sebesar 29,698

\begin{tabular}{|c|c|c|c|c|c|c|}
\hline & & & Co & efficients $^{\mathrm{a}}$ & & \\
\hline & & $\begin{array}{r}\text { Unstand } \\
\text { Coeffi }\end{array}$ & $\begin{array}{l}\text { ardized } \\
\text { ients }\end{array}$ & \begin{tabular}{|} 
Standardized \\
Coefficients
\end{tabular} & $T$ & Sig. \\
\hline & Model & B & $\begin{array}{l}\text { Std. } \\
\text { Error }\end{array}$ & Beta & & \\
\hline 1 & (Constant) & 6.989 & 9.650 & & .724 & .471 \\
\hline & $\begin{array}{l}\text { Antroposentris } \\
\text { (X1) }\end{array}$ & .044 & .265 & .016 & .168 & .867 \\
\hline & Ekosentris (X2) & -1.227 & .443 & .294 & 2.771 & .007 \\
\hline & Biosentris $(\mathrm{X} 3)$ & -.780 & .483 & -.172 & -1.614 & 110 \\
\hline
\end{tabular}
yang ada pada persamaan di atas, menunjukan besarnya nilai rata-rata tingkat perilaku vandalisme tanpa dipengaruhi oleh aspek pemahaman lingkungan di Taman teras Cikapundung.

Tabel 7. Regresi Linier Berganda Taman

\section{Lansia}

Sumber: Hasil Olahan Menggunakan SPSS

Versi 20.0, 2016

Persamaan regresi yang menjelaskan pengaruh pemahaman lingkungan Antroposentris $\left(\mathrm{X}_{1}\right)$, Ekosentris $\left(\mathrm{X}_{2}\right)$ dan Biosentris $\left(\mathrm{X}_{3}\right)$ terhadap perilaku vandalisme (Y) pengunjung Taman Lansia adalah sebagai berikut:

Nilai konstanta $(a)$ sebesar 6,989 yang ada pada persamaan di atas, menunjukan besarnya nilai rata-rata tingkat perilaku vandalisme tanpa dipengaruhi oleh aspek pemahaman lingkungan di Taman Lansia.

Koefisien korelasi berganda ini digunakan untuk mengetahui derajat asosiasi atau kekuatan hubungan yang terjadi antara Pemahaman Lingkungan secara simultan dengan tingkat perilaku vandalisme pengunjung. Dengan menggunakan bantuan software SPSS diperoleh hasil sebagai berikut:

Tabel 8. Koefisien Korelasi Berganda Taman Teras Cikapundung Model Summary

\begin{tabular}{lrrrr}
\hline Model & $\mathbf{R}$ & R Square & $\begin{array}{c}\text { Adjusted R } \\
\text { Square }\end{array}$ & $\begin{array}{c}\text { Std. Error of } \\
\text { the Estimate }\end{array}$ \\
\hline 1 & $.381^{\mathrm{a}}$ & .145 & .118 & 5.74786 \\
\hline
\end{tabular}


Rizki Widya Witami, Rosita dan Sri Marhanah: Pengaruh Pemahaman Lingkungan Terhadap

Perilaku Vandalisme Pengunjung Taman Teras Cikapundung dan Taman Lansia Bandung

a. Predictors: (Constant), Biosentris (X3), Antroposentris (X1), Ekosentris (X2)

Sumber: Hasil Olahan Menggunakan SPSS Versi 20.0, 2016

Berdasarkan tabel 8 diatas menujukkan bahwa nilai korelasi simultan (R) yang diperoleh adalah sebesar 0,381. Skor tersebut termasuk dalam kategori adanya hubungan yang lemah dikarenakan berada pada interval korelasi antara 0,20 0,399 .

Tabel 9. Koefisien Korelasi Berganda Taman Lansia

Model Summary

\begin{tabular}{llrrr}
\hline Model & $\mathbf{R}$ & $\mathbf{R}$ Square & $\begin{array}{c}\text { Adjusted R } \\
\text { Square }\end{array}$ & $\begin{array}{r}\text { Std. Error of } \\
\text { the Estimate }\end{array}$ \\
\hline 1 & $.333^{\text {a }}$ & .111 & .083 & 6.64521 \\
\hline a. Predictors: & (Constant), & Biosentris & $(\mathrm{X} 3)$, & Antroposentris
\end{tabular}

(X1), Ekosentris (X2)

Sumber: Hasil Olahan Menggunakan SPSS Versi 20.0, 2016

Berdasarkan tabel 9 menujukkan bahwa nilai korelasi simultan (R) yang diperoleh adalah sebesar 0,333. Skor tersebut termasuk dalam kategori adanya hubungan yang lemah dikarenakan berada pada interval korelasi antara 0,20-0,399.

Uji Hipotesis dilakukan untuk menguji hipotesis penelitian yang dilakukan dengan cara uji koefisien determinasi, uji $\mathrm{F}$ dan uji $\mathrm{T}$ dengan menggunakan bantuan software SPSS.

Uji Koefisien determinasi merupakan nilai yang menunjukkan besar kontribusi pengaruh yang diberikan oleh pemahaman Antroposentris $\left(\mathrm{X}_{1}\right)$, Ekosentris $\left(\mathrm{X}_{2}\right)$ dan Biosentris $\left(\mathrm{X}_{3}\right)$ terhadap perilaku vandalisme (Y). Hasil pengujian koefisien determinasi dapat dilihat pada tabel berikut:

Tabel 10. Uji Koefisienan Determasi Taman Teras Cikapundung Model Summary

\begin{tabular}{lcccr}
\hline Model & $\mathbf{R}$ & $\begin{array}{c}\mathbf{R} \\
\text { Square }\end{array}$ & $\begin{array}{c}\text { Adjusted } \\
\text { R Square }\end{array}$ the Estimate \\
\hline 1 & $.381^{\mathrm{a}}$ & .145 & .118 & 5.74786 \\
\hline a. Predictors: & (Constant), & Biosentris & $(\mathrm{X} 3)$, \\
Antroposentris (X1), Ekosentris (X2) & \\
Sumber: Hasil & Olahan & Menggunakan & SPSS \\
Versi 20.0, 2016 & & &
\end{tabular}

Berdasarkan tabel di atas, dapat dilihat bahwa nilai R-square yang diperoleh dari data olahan responden Taman Teras Cikapundung adalah sebesar 0,145 (14,5\%). Hasil tersebut menujukkan jika pemahaman lingkungan Antroposentris $\left(\mathrm{X}_{1}\right)$, Ekosentris $\left(\mathrm{X}_{2}\right)$ dan Biosentris $\left(\mathrm{X}_{3}\right)$ secara simultan memberikan kontribusi pengaruh sebesar 14,5\% terhadap perilaku vandalisme Taman Teras Cikapundung, sedangkan (1-R $\left.{ }^{2}\right)$ sebesar $85,5 \%$ sisanya merupakan besar kontribusi pengaruh yang diberikan oleh faktor lainnya yang tidak diteliti.

Tabel 11. Uji Koefisienan Determasi

Taman Lansia

Model Summary

\begin{tabular}{lcccr}
\hline Model & $\mathbf{R}$ & $\begin{array}{c}\mathbf{R} \\
\text { Square }\end{array}$ & $\begin{array}{c}\text { Adjusted } \\
\mathbf{R} \text { Square }\end{array}$ & $\begin{array}{r}\text { Std. Error of } \\
\text { the Estimate }\end{array}$ \\
\hline 1 & $.333^{\text {a }}$ & .111 & .083 & 6.64521 \\
\hline a. & Predictors: & (Constant), & Biosentris & $(\mathrm{X} 3)$,
\end{tabular}

Antroposentris (X1), Ekosentris (X2)

Sumber: Hasil Olahan Menggunakan SPSS

Versi 20.0, 2016

Berdasarkan tabel di atas, dapat dilihat bahwa nilai R-square yang diperoleh dari data olahan responden Taman Lansia adalah sebesar $0,111 \quad(11,1 \%)$. Hasil tersebut menujukkan jika pemahaman lingkungan Antroposentris $\left(\mathrm{X}_{1}\right)$, Ekosentris $\left(\mathrm{X}_{2}\right)$ dan Biosentris $\left(\mathrm{X}_{3}\right)$ secara simultan memberikan kontribusi pengaruh sebesar $11,1 \%$ terhadap perilaku vandalisme Taman Lansia, sedangkan $\left(1-\mathrm{R}^{2}\right)$ sebesar $88,9 \%$ sisanya merupakan besar kontribusi pengaruh yang diberikan oleh faktor lainnya yang tidak diteliti.

Uji $\mathrm{T}$ digunakan untuk mengetahui pengaruh masing-masing variabel bebas terhadap variabel terikat.

Tabel 12. Uji T Parsial Taman Teras Cikapundung

\begin{tabular}{ccccccc}
\hline Variabel & $t_{\text {hitung }}$ & $t_{\text {tabel }}$ & Sig. & $\boldsymbol{\alpha}$ & Kep & Ket \\
\hline $\begin{array}{c}\text { Antroposentris } \\
\left(X_{1}\right)\end{array}$ & 0.019 & 1,985 & 0.985 & 0,05 & $\begin{array}{c}\text { Ho } \\
\text { ditolak }\end{array}$ & $\begin{array}{c}\text { Tidak } \\
\text { Sig }\end{array}$ \\
\hline Ekosentris $\left(X_{2}\right)$ & -2.495 & 1,985 & 0.014 & 0,05 & $\begin{array}{c}\text { Ho } \\
\text { diterima }\end{array}$ & Sig \\
\hline Biosentris $\left(X_{3}\right)$ & -1.295 & 1,985 & 0.198 & 0,05 & $\begin{array}{c}\text { Ho } \\
\text { ditolak }\end{array}$ & $\begin{array}{c}\text { Tidak } \\
\text { Sig }\end{array}$ \\
\hline
\end{tabular}

Sumber: Olahan Penulis, 2016 
Berdasarkan data hasil uji T pada tabel 12 diatas dengan tingkat signifikansi $(\alpha)$ yang digunakan adalah sebesar 0,05 atau $5 \%$, maka hipotesis yang didapatkan yaitu:

Pemahaman Antroposentris tidak berpengaruh signifikan terhadap perilaku vandalisme pengunjung, pemahaman Ekosentris berpengaruh signifikan terhadap perilaku vandalisme pengunjung dan pemahaman Biosentris tidak berpengaruh signifikan terhadap perilaku vandalisme pengunjung Taman Teras Cikapundung.

Tabel 13. Uji T Parsial Taman Lansia

\begin{tabular}{ccccccc}
\hline Variabel & $t_{\text {hitung }}$ & $t_{\text {tabel }}$ & Sig. & $\alpha$ & Kep & Ket \\
\hline $\begin{array}{l}\text { Antroposentris } \\
\left(X_{1}\right)\end{array}$ & 0.168 & 1,985 & 0.867 & 0,05 & $\begin{array}{l}\text { Ho } \\
\text { ditolak }\end{array}$ & $\begin{array}{c}\text { Tidak } \\
\text { Sig }\end{array}$ \\
\hline Ekosentris $\left(X_{2}\right)$ & 2.771 & 1,985 & 0.007 & 0,05 & $\begin{array}{l}\text { Ho } \\
\text { diterima }\end{array}$ & Sig \\
\hline Biosentris $\left(X_{3}\right)$ & -1.614 & 1,985 & 0.110 & 0,05 & $\begin{array}{l}\text { Ho } \\
\text { ditolak }\end{array}$ & $\begin{array}{c}\text { Tidak } \\
\text { Sig }\end{array}$ \\
\hline
\end{tabular}

Sumber: Olahan Penulis, 2016

Berdasarkan data hasil uji T pada tabel 13 diatas dengan tingkat signifikansi $(\alpha)$ yang digunakan adalah sebesar 0,05 atau $5 \%$, maka hipotesis yang didapatkan yaitu: Pemahaman Antroposentris tidak berpengaruh signifikan terhadap perilaku vandalisme pengunjung, pemahaman Ekosentris berpengaruh signifikan terhadap perilaku vandalisme pengunjung dan pemahaman Biosentris tidak berpengaruh signifikan terhadap perilaku vandalisme pengunjung Taman Lansia.

Uji $F$ digunakan sebagai uji simultan untuk melihat pengaruh pemahaman lingkungan Antroposentris $\left(\mathrm{X}_{1}\right)$, Ekosentris $\left(\mathrm{X}_{2}\right)$, dan Biosentris $\left(\mathrm{X}_{3}\right)$ terhadap variabel perilaku vandalisme (Y). Berikut adalah hasil pengolahan software SPSS 20.0 mengenai Uji F:

Tabel 14. Uji F Taman Teras Cikapundung ANOVA $^{\mathrm{a}}$

\begin{tabular}{llrrrrr}
\hline Model & $\begin{array}{c}\text { Sum of } \\
\text { Squares }\end{array}$ & df & $\begin{array}{c}\text { Mean } \\
\text { Square }\end{array}$ & F & Sig. \\
\hline 1 & $\begin{array}{l}\text { Regressi } \\
\text { on }\end{array}$ & 537.461 & 3 & 179.154 & 5.423 & $.002^{b}$ \\
\hline $\begin{array}{l}\text { Residual } \\
\text { Rotal }\end{array}$ & 3171.633 & 96 & 33.038 & & \\
\hline Total & 3709.094 & 99 & & & \\
\hline
\end{tabular}

a. Dependent Variable: Perilaku Vandalisme $(\mathrm{Y})$ b. Predictors: (Constant), Biosentris (X3), Antroposentris (X1), Ekosentris (X2)

Sumber: Hasil Olahan Menggunakan SPSS Versi 20.0, 2016

Berdasarkan Tabel 14 dapat disimpulkan bahwa $F_{h} 5,423>F_{t} 2,69$ yang berarti bahwa pada taraf nyata $\alpha=5 \%$ variabel Pemahaman Lingkungan signifikan berpengaruh terhadap perilaku vandalisme di Taman Teras Cikapundung.

Tabel 15. Uji F Taman Lansia ANOVA $^{a}$

\begin{tabular}{lcrccc}
\hline Model & $\begin{array}{c}\text { Sum of } \\
\text { Squares }\end{array}$ & df & $\begin{array}{c}\text { Mean } \\
\text { Square }\end{array}$ & F & Sig. \\
\hline 1 Regression & 529.400 & 3 & 176.467 & 3.996 & $.010^{\mathrm{b}}$ \\
\hline Residual & 4239.242 & 96 & 44.159 & & \\
\hline Total & 4768.642 & 99 & & & \\
\hline
\end{tabular}

a. Dependent Variable: Perilaku Vandalisme (Y)

b. Predictors: (Constant), Biosentris (X3), Antroposentris (X1), Ekosentris (X2)

Sumber: Hasil Olahan Menggunakan SPSS Versi 20.0, 2016

Berdasarkan Tabel 15 dapat disimpulkan bahwa $F_{h} 3,996>F_{t}$ 2,69 yang berarti bahwa pada taraf nyata $\alpha=5 \%$ variabel Pemahaman Lingkungan signifikan berpengaruh terhadap perilaku vandalisme di Taman Lansia.

\section{KESIMPULAN}

Pemahaman pengunjung Taman Teras Cikapundung dan Taman Lansia terhadap pemahaman Antroposentris berada pada kategori "cukup paham", hal tersebut dikarenakan masih banyak pengunjung yang tidak setuju dengan pemahaman bahwa alam harus dieksploitasi semaksimal mungkin oleh manusia. pemahaman lingkungan Ekosentris berada pada kategori "sangat paham", hal tersebut dikarenakan pengunjung sangat memahami bahwa manusia adalah bagian dari ekosistem alam. Pemahaman lingkungan Biosentris berada pada kategori "paham" hal tersebut dikarenakan pengunjung memahami bahwa alam berhak untuk dihargai. Dapat ditarik kesimpulan bahwa pengunjung Taman Teras Cikapundung dan Taman Lansia 
Rizki Widya Witami, Rosita dan Sri Marhanah: Pengaruh Pemahaman Lingkungan Terhadap Perilaku Vandalisme Pengunjung Taman Teras Cikapundung dan Taman Lansia Bandung

menyatakan paham terhadap pemahaman mengenai lingkungan.

Perilaku vandalisme yang terjadi di Taman Teras Cikapundung dan Taman Lansia sebagian kecil terdapat pada kriteria "tidak pernah" yang mana artinya sebagian besar pengunjung Taman Teras Cikapundung dan Taman Lansia Bandung pernah melakukan perilaku vandalisme di taman kota.

Total kontribusi pengaruh yang diberikan oleh ketiga variabel tersebut terhadap Taman Teras Cikapundung adalah sebesar 14,48\% dan Taman Lansia sebesar $8,08 \%$, sisanya dipengaruhi oleh faktor lain yang tidak diteliti. Pemahaman lingkungan yang berpengaruh signifikan terhadap tingkat perilaku vandalisme di Taman Teras Cikapundung dan Taman Lansia ialah pemahaman lingkungan Ekosentris. Pemahaman ini dapat secara signifikan berpengaruh menurunkan tingkat perilaku vandalisme di taman kota karena pada pemahaman ini menyebutkan bahwa manusia sebagai bagian dari ekosistem alam dan sangat memahami bahwa kondisi lingkungan akan selalu berimbas pada kehidupannya. Sehingga dengan pemahaman tersebut maka pengunjung akan berfikir kembali untuk melakukan perilaku vandalisme di Taman Teras Cikapundung dan Taman Lansia Bandung.

\section{DAFTAR PUSTAKA}

Arikunto. (2010). Prosedur Penelitian: Suatu Pendekatan Praktek. Jakarta: Rineka Cipta..

Cohen, S. (1973). Property destruction : Motives and Meanings. In C.Ward (ed). Vandalism. London : Architectural Press.

Hamzah, S. (2013). Pendidikan Lingkungan: Sekelumit Wawasan Pengantar. Bandung : Refika Aditama.

Haryadi, B. Setiawan. (1995). Arsitektur Lingkungan dan Perilaku: Suatu Pengantar ke Teori, Metodologi dan Aplikasi. Jakarta : Direktorat Jendral Pendidikan Tinggi.

Nazir, Moh. (1988). Metode Penelitian. Jakarta : Ghalia Indonesia. 